THE IMPORTANCE OF ANIMAL EXPERIMENTATION

FOR SAFETY AND BIOMEDICAL RESEARCH 


\section{The Importance of Animal Experimentation for Safety and Biomedical Research}

edited by

S. Garattini

Pharmacological Research Institute 'Mario Negri'

Milan

Italy

and

D.W. van Bekkum

Radiobiological Institute 'TNO'

Rijswijk

The Netherlands

Kluwer Academic Publishers

Dordrecht / Boston / London 


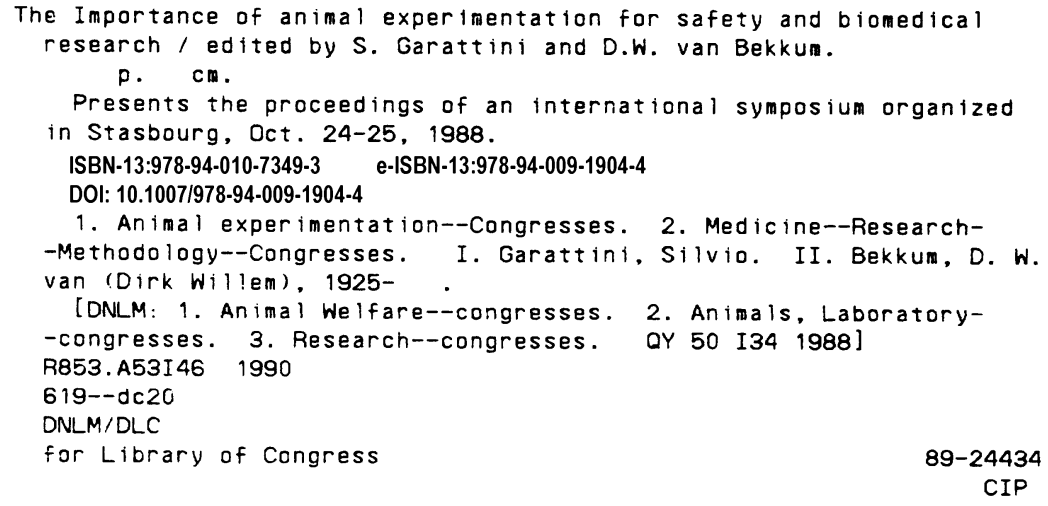

Published by Kluwer Academic Publishers,

P.O. Box 17, 3300 AA Dordrecht, The Netherlands.

Kluwer Academic Publishers incorporates the publishing programmes of

D. Reidel, Martinus Nijhoff, Dr W. Junk and MTP Press.

Sold and distributed in the U.S.A. and Canada

by Kluwer Academic Publishers,

101 Philip Drive, Norwell. MA 02061, U.S.A.

In all other countries, sold and distributed

by Kluwer Academic Publishers Group,

P.O. Box 322, 3300 AH Dordrecht, The Netherlands.

printed on acid free paper

All Rights Reserved

(c) 1990 by Kluwer Academic Publishers

No part of the material protected by this copyright notice may be reproduced or utilized in any form or by any means, electronic or mechanical including photocopying, recording or by any information storage and retrieval system, without written permission from the copyright owner. 


\section{Table of Contents}

Foreword

The necessity of animal experimentation

S. Garattini

ETHICAL AND LEGAL ASPECTS

Animal experimentation defended

C. Cohen

The ethics of animal use in biomedicine

T.L.S. Sprigge

Legal and political problems of animal experimentation, the 'Swiss battle'

F. Bridel

Experimentation and the law

J.M. Varaut

Experimentation on animals: animals as machines and animals as fetishes

J. Chanteur

RECENT PROGRESS OF MEDICINE REQUIRING

THE USE OF ANIMALS

The role of animal experiments in pharmacological brain research
A. Carlsson

Regeneration of the nervous system

A. Gorio \& F. Cattabeni

Endocrine glands, neuroendocrinology and animal experimentation

P. Preziosi

Laboratory animals and cardiovascular pathology: means for better use

J. Sassard

The importance of animal models for hypertension research

D. Ganten, K. Lindpaintner, Th. Unger \& J. Mullins 
Animal experiments and recent progress in thrombosis research

G. de Gaetano, C. Cerletti, A. Poggi \& M.B. Donati

Models of human renal disease

C. Zoja, N. Perico \& G. Remuzzi

The necessity of animal experimentation in tumor immunology

G. Forni, P. Caretto, P. Ferraiorni, M.C. Bosco \& M. Giovarelli 125

The use of animals in cancer chemotherapy

T.A. Connors

The use of experimental animals in transplantation research

D.W. van Bekkum

Animal models for AIDS research

P. Bentvelzen

The need for animal experimentation in drug and vaccine development against tropical diseases

$$
\text { A. Moncayo }
$$

USE OF ANIMALS FOR SAFETY REASONS

Toxicology: role of in vivo studies in establishing mechanisms of toxicity

$$
\text { J.W. Bridges }
$$

Necessity of animal experiments for the safety evaluation and necessary consequences for public health

J.R. Claude \& H. Dutertre-Catella

The necessity of animal testing for safety evaluation and medical progress in reproductive biology and toxicology

D. Neubert

The need for animal experimentation in studying the carcinogenic risk of substances

I. Chouroulinkov

THE FUTURE OF ANIMAL RESEARCH

Transgenic animals for human diseases and gene therapy

M. Rossini, E. Di Martino \& G. Bensi

Recent progress toward reducing the use of animal experimentation in biomedical research

M. Balls

Animal use in drug research

M. Kramer 


\section{Foreword}

Scientists are coming under increasing pressure from activist groups to stop animal experimentation, branded as cruel and unnecessary for improving human health. This attitude, however, stems from an unrealistic evaluation of the situation and distorted information about present scientific knowledge.

There is no question that most medical progress - perhaps all, in fact has been attained through knowledge derived initially from experiments in various animal species. There is practically no way of replacing animals in these investigations and so-called 'alternative methods' are in reality merely complementary. Tissue cultures, cell, microorganisms, enzymes, membranes, mathematical models - all are useful for preliminary screening tests and for testing hypotheses, but the complexity of a living organism is such that in vivo studies are essential before any test can responsibly be made in man.

This book presents the proceedings of an international symposium organized in Strasbourg (October 24-25, 1988), with the aim of assessing present-day requirements as regards animal experimentation in research related to major medical and toxicological problems still awaiting solutions.

Analysis of these chapters will convince any unbiased reader that animals are still needed in the laboratory. However on the positive side scientists are finding ways of using ever-fewer animals as advances are made in technology and non-invasive investigational methods become accessible on a wide scale. 